\title{
ЛИСТ МИРОНА БУДИНСЬКОГО ДО ОЛЕКСИ МИШАНИЧА (1970) В КОНСТЕКСТІ ПИТАННЯ ІДЕНТИЧНОСТІ РУСИНІВ БАЧКИ І СРЕМА
}

У статті розглянуто ставлення письменника Мирона Будинського до питання ідентичності русинів Бачки і Срему. Стаття містить неопублікований лист М.Будинського до українського науковця О.Мишанича.

Ключові слова: Мирон Будинський, Олекса Мшанич, Михайло Ковач, Югославія, русини, українці, ідентичність

Мирон Будинський (Будински; 1931-2018) - відомий поет і письменник 3 громади русинів Бачки і Срема, лауреат літературних премій, педагог і науковий працівник середніх і вищих навчальних закладів у Югославії. Ще школярем, 1948 р. починає публікувати свої літературні твори; протягом наступних десятиріч його прозу і поезію друкують у місцевих часописах, календарях, збірках і підручниках, а також за кордоном у перекладі (Тамаш 1997: 509-511; Чурчич 2006: 505-507). Член товариства письменників Воєводини з 1971 р. Його ім'я вперше потрапило до сторінок газети "Руске слово" 1945 р., коли він навчався в гімназії в Руському Керестурі, про що згадано у опублікованій промові директора школи Гавриїла Надя від 26 серпня 1945 р. (Конєи школского року, 1945).

Своє ставлення до питання ідентичності меншини русинів Бачки і Срема Будинський висловлює зі сторінок газети "Руске слово": 14 січня 1955 р. редакція публікує його допис за назвою Думки з нагоди Дзешещрочеїи и снованя нашей гимназиї (Здогадованя). У статті йдеться про заснування гімназії у Руському Керестурі (відбулося 25 лютого 1945 р.) та про питання вибору мови, якою слід було викладати предмети у цьому навчальному закладі. Будинський розповідає, що один з учителівзасновників гімназії, Йовген Планчак (1914-1977), поставив цей вибір на голосування перед присутніми членами громади. Цей вчитель, додамо, підтримував ідею, згідно якої русини у мовно-культурному 
аспекті $є$ частиною українського народу (Румянцев 2010: 259-260). На першому голосуванні були присутні здебільшого представники інтелігенції і перевагу було віддано українській мові, однак у декого 3 присутніх виникли й сумніви щодо такого вибору, тому було вирішено провести другу нараду. На другій нараді, за присутності широких верств громади, більшість підтримала російську мову, але за таких обставин:

Народ теди як лєв згажел интелигенцию и єй українски романтизам; теди двацецрочна предвойнова робота священїкох и учительох "Українцох" випатрала така бидна, нїчтожна... И тераз ю сануєм кед ше здогадам на то... Народ $з$ одушевийом, нє дозволюючи до прочивна страна (теди то наисце була процивпїцка) придзе до вираженя, одгласал же наставни язик ма буц велькоруски (Будински 1955).

Щоб з'ясувати причини цього культурного антагонізму (що не $\epsilon$ метою цієї статті), слід звернутися до вже опублікованих матеріалів ${ }^{1}$ та розглянути причини конфлікту між інтелігенцією, що запроваджувала культурно-просвітницьку працю в лавах Руського народного просвітного товариства (1919-1941), та тими представниками громади, що гуртувалися навколо Культурно-просвітницького союзу югославських русинів (1933-1941). Зауважимо, що описаний у цитаті вибір російської мови не можна трактувати однозначно - зокрема тому, що Будинський у допису не з'ясовує ані якісно, ані кількісно поняття ‘народ’, а також тому, що представникам інтелігенції, тобто освіченій частині громади, просто не надали слова. Специфічне вживання словосполучення “український романтизм”, навпаки, дозволяє нам зрозуміти особистий підхід Будинського до поставленої проблематики: він підтримував не інтелігенцію 3 іiі проукраїнським ставленням, а доволі абстрактний 'народ’.

Утім, остаточне рішення - тобто висновок щодо вживання у освіті літературної мови русинів Бачки і Срема - схвалено на третіх зборах, після інтервенції впливового активіста, педагога Якима Бакова (1906-1974). На цих зборах, за присутності вже меншої кількості людей,

\footnotetext{
${ }^{1}$ Найважливіший науковий доробок на цій царині, на нашу думку, зібрано у публікації: Рамач, Я. На крижней драги. Руснаии у Югославиї од 1918-1941. року. Нови Сад: Руске слово, 2016.
} 
слово отримав лише він, про що Будинський згадує із певним романтизмом:

Я теди (бул сом тринац рочни хлапец) чувствовал у тих словох цошка нєпреповедзено миле и блїзке, а нєшка видзим же професор Баков найреалнєйше патрел на обставини, бо гоч наш язик бучваньско-руски, анї нє бул брати до огляду як наставни язик и гоч професор Баков бул сам, його думанє победзело и победзує.

Ставлення Бакова до питання ідентичності русинів ми вже висвітлювали в інших публікаціях (Румянцев 2010: 256, 261, 265-269; Румянцев 2015). Будинський 3 відвертою пошаною поставився до Бакова та цілком підтримав запропоновану лінію на обставляння власної мови і культури як автохтонної:

Нє дайме ше вецей залудзовац 3 українизмом, та анї 3 другима “измами”. Наша драга то стваряне нового литературного язика и новей култури. Ми то и робиме, ми то и робели, то робели и предвойново “Українци”, алє ми треба да знаме цо робиме! Нє шмеме робиц шлєпо! А же зме робели шлєпо можу нам послужиц як доказ и горе описани події.

Цікаво, що Будинський визнає корисність праці проукраїнської інтелігенції у міжвоєнний період, але вимагає переусвідомлення іiі культурної спадщини. Як відомо, суто інтелігенція за часів заснування у 1919 p. згаданого вище просвітного товариства обгрунтувала необхідність вживати у культурницькому житті й освіті власну літературну мову (а не українську, і не “язичіє”) та створила умови для реалізації іiі потенціалу на сторінках місцевих видань. Однак ця інтелігенція усвідомлювала, що для розвитку власного етнокультурного середовища потрібна взаємодія з культурою походження, i тому обгрунтовувала ідею належності русинів до української спільноти. Суто цей аспект Будинський вважає вадою, недоречною ідеологією (тобто “-ізмом”), та пропонує вилучити його з культурницького життя меншини. "Робиц шлєпо”, на думку Будинського, означає безпосередньо втілювати взаємодію 3 українською культурою, ігноруючи ставлення 'народу'. У останньому реченні цитати автор застерігає: за умови недотримання такого ставлення, 'народ' дасть себе почути. Як бачимо, Будинський - а він, цілком зрозуміло, у цій статті 
цікавить нас виключно як представник певного світогляду - вважає вирішальними не аргументи інтелігенції, що їх студент навіть не наводить, а ментальність певної етнічної спільноти, на яку й слід було нібито орієнтуватися.

Наприкінці допису Будинський ставить низку риторичних запитань та залучає до дискусії постать відомого письменника Михайла Ковача (1909-2005):

Прецо народ Керестура, у дньох снованя нашей гимназиї бул одлучно процив українского язика, як наставного, кед ше (по словох Михала Ковача) наш народ “чувствує” українским и то, попри двацец або трицецрочней роботи и пропагираня же наш народ то часц українского народу а наша кнїжовна бешеда то українска бешеда?

Прецо народни, бачваньскоруски язик победзел у нашей гимназиї?

Чи ше нє може уж тераз, на основу розвою нашого язика од Першей шветовей войни та по нєшка, на основу горе написаних подийох и на основу побиди нашого язика у наших школох, же українизам то цошка вештачке у нашим народзе, же ше нє приял и же одумер; же українизам то файта - фурма романтизму (у двацетим вику!) у нашим народзе, створена за малих пре пре чувство велькосци и достоянства?

Питання Будинського $є$ риторичним, отже містить у собі й відповідь. У своїй статті він вимагає офіційної відмови від ідеї належності мови і культури русинів до українського контексту (“фурма романтизму"), оскільки вбачає у ній наявність певного привілею (або “чувство велькосци и достоянства") тієї інтелігенції, яка, включно 3 М.Ковачем, вважала себе належною до українського контексту. Цей нібито привілей, насправді, полягав у певній авторитетності цього прошарку інтелігенції, зокрема письменників, оскільки ці діячі шукали й демонстрували читачеві коріння громади 3 метою збереження іiї ідентичності. Для пояснення цього ставлення наведемо таку цитату Ковача:

[...] коли наш письменник пише для руснака і хоче його просвітити, що він повинен своє любити і шанувати, а сам не потрудиться, як інтелігент, як сіль народу, щоб відшукати коріння свого народу, 3 
якого ми тут на цій рівнині соки пили, то він свідомо діє на скорочення віку тої нашої белетристики, за яку ми так вперто боремося, щоб іiі вивести на широку дорогу між людей (Софронів-Левицький, 1970: 56).

Вимога Будинського, по-перше, свідчить про очевидний факт: так звана 'перемога' (“побида”) не була власне перемогою, адже, як свідчить сам Будинський, від “українізму” ще слід було відмовитися. Ніхто 3 представників інтелігенції звичайно не вважав, що слід зрікатися своїх ставлень до питання ідентичності лише тому, що певна частина громади (знов таки, 'народ’) ухвалила певне рішення.

По-друге, Югославія, як відомо, намагалася трактувати цю меншину як суто югославську, тобто автохтонну, ${ }^{2}$ та надавала підтримку тим представникам русинів, що обстоювали цей автохтонний світогляд. Про штучне, вертикальне створення такого статусу цієї меншини (буквально: "status di minoranza proveniente dall'alto") вже писав італійський дослідник Лука Кальві (Calvi, 1999: 143-144). Політичні привілеї нової русинсько-югославської інтелігенції гарантували державі певну форму югославського слов'янського патріотизму та були несумісними 3 культурними 'привілеями' тієї інтелігенції, що вважала за необхідне шукати власну ідентичність за межами Югославії, “у глибині”,3 власної історії.

Прихильна відповідь на риторичне питання Будинського надійшла у наступному номері газети "Руске слово”, у анонімній (sic!) статті Мушиме трезбейше патрии на Українизам. У цій відповіді, згідно звичної риторики великоросійського шовінізму, було

2 Слід зауважити, що результати переписів населення від 1948, 1953 та 1961 pр. містили єдину категорію “русини-українці”, та починаючи лише з 1971 року інформацію розподілено по двох окремих категоріях. (Румянцев, 2010: 273, 347).

3 Для пояснення терміну наводимо відповідні слова М.Ковача: «У плиткім черепку можна лиш таку рослину плекати, яка не вимагає землі на глибоке коріння. Вона обмежена до свого черепка і може прикрашувати чиєсь обійстя лиш під умовою, що найдеться хтось на тому обійстю, хто буде дбати, щоб ця рослина мала подостатком вологости і тепла. Щоб вона сама могла рости, розвиватися, пускати коріння і приносити овочі, їй потрібна глибина» (Софронів-Левицький, 1970: 55). 
'роз'яснено', що українська ідея - це нібито політична програма Німеччини та Ватикану, та що “українство” (очевидно, у вигляді ‘привілею') було для греко-католицького духовенства нібито засобом поширення власного впливу: "Українєц цо го керестурски паноцове сцели сцели створиц 3 руснака випатрал би так: боси чловек у ватиканских гачох, у гитлеровскей кошулї з крижом, загнуту бундасту шапку з трозубом и з молитвенїком у руки, а з упартима очми на образи святого Гитлера и римского оца" (Х.X., 1955: 3). Не будимо далі зупинятися на таких 'аргументах' - їх наведено лише 3 метою продемонструвати особливості діалектики опонентів М.Ковача та його однодумців. Статті такого змісту, що належали Ш.Чаканові, Я.Сегеді, Д.Сабадошеві, Я.Сабадошеві тощо, з'являлися на сторінках цієї газети і раніше (Румянцев, 2010: 255-264).

У колах української діаспори постать Будинського сприймали критично. Український науковець Олекса Горбач 1955 р. у листі до М.Ковача писав, що нелегко "усунути баламутність таких панів Будинских і Сабадошів”, які сіють розбрат між своїм народом (Рамач, 2019: 130).

Наведена вище інформація допомагає охарактеризувати кшталт культурно-суспільних поглядів Будинського. Звичайно, йшлося про світогляд 24-річного студента, однак цей діяч вже публікував свої художні твори, що у певній мірі свідчить про його зрілість і схильність до самовираження. Треба також додати, що відомий літературознавець, академік Юліян Тамаш писав про нелегку долю плеяди письменників, до якої належав Будинський: “Судьба тей генерациї була чежка: уж на самим початку єї дійствованя од 1954-1964. року, пада период цихосци и прерви организованого литературного живота. Тот факт зохабел обачлїви шлїди и їх дїлу, у першим шоре пре одредзену нєсигурносц и дезориентацию после 1964. року, пре хтору ше єдна часц тей генерациї писательох нє лєм чежко знаходзела, алє и одуставала од писаня" (Тамаш, 1997: 202). Відомо, що у 1970-х рр. Будинський “пре обєктивни причини” припинив співпрацю з локальною періодикою русинів (Умар Мирон Будински, 2018). Також відомо, що він і надалі дотримувався своїх дотеперішніх поглядів, що підтверджує його допис від 1970 року, у якому він розповідає про становлення культурницького життя і освіти у громаді і згадує Я.Бакова як захисника мови русинів у освіті (Будински, 1970: 46). 
У жовтні 1972 p. Будинський надсилає до українського академіка Олекси Мишанича (1933-2004) свою книжку „Воденїчка на стриберним потоку“, яку Тамаш (1997:203) охарактеризував як “животне дїло” Мирона Будинського. Ця публікація отримала широке визнання у рамках Сербії: у 1970 р. письменник отримав за неї літературну премію “Невен” (існує 31955 р.). Книжку буде двічі перевидано у наступні роки.

Як відомо, О.Мишанич вже багато років вивчав літературну спадщину громади русинів Бачки і Срему, приїздив до Югославії та листувався 3 багатьма представниками місцевої інтелігенції. Він був ознайомлений із творчістю Будинського, а про надіслану йому книжку вже знав принаймні з листа Ковача від 25 вересня 1972 р.: у листі Ковач доволі критично відізвався про Будинського, а щодо його публікації написав:

Тепер нагороду за найліпшу книжку „комісії” поділили Ш. Чакана „Басні” ${ }^{4}$ та М. Будинского „Воденічка”. Перший вже по заголовку бачиш куди тягне бо „басни” це сербизм, а той другий за цю саму книжку одержав два премії, хоч на мою думку воно погана імітація народного оповідання, як і „Данко Здогаданко” 5 імітація „Яника Мальованого" 6 . Та треба знати що це - Мирон Будинськи який $\epsilon$ ворогом „украінізаціі”... Лише ці два приклади говорять багато про наші обставині.

У попередній частині допису ми вже стисло описали ставлення Будинського до так званого 'національного' питання, тому годі приховувати, що натрапити на лист борця проти “українизма" до українського науковця було несподіванкою. 3 іншого боку, як свідчить інформація Відділу рукописних фондів і текстології Інституту літератури ім. Т.Г. Шевченка НАН України, до О.Мишанича зверталися й інші представники автохтонної русинської течії.

\footnotetext{
${ }^{4}$ Ш.Чаканові премію надано 1972 р.

${ }^{5}$ Одноіменну збірку праць Будинського видано у 1982 р.

${ }^{6}$ Це підтверджує і Ю.Тамаш (1997, 202-203).
} 
Наводимо текст листа:

Дороги товариш Мишанич,

Посилам Вам свою єдину кнїжку. Вона написана за дзещи. Одучел сом ше написач сказки прето же по мойм думаню вони даваю писательови найвекшу шлєбоду и же их шицки людзе у швеце розумя т.є. же вони представяю якиш медзинародни язик. Вони, медзитим, написани на язику котри ма барз огранїчене дійство, на котрим бешедує барз мале число людзох. Не чежко веи одгаднуи же тота файта кнїжовного дїла - сказка - треба же би ми компензовала огранїченоси язика на котрим бешедуєм и пишем. Шицки ми, котри питеме на тим язику пре його органїченоси нєщешлїв алє и упорни. Нє чудо веи же зме часто и наивни ти глєдаме людзох у далєким швеце котри би нам могли отвории облак до швета. Вашо отечество таке вельке и цали швет упера погляди на вас, та нє чудо же ше и ми поволусме на Вас, гоч то напевно барз наивне.

Кнїжка крашне прията зоз боку наших дзецох, а достала и ширше признанє - награду "Невен” на Змайових дзецинских бавискох 1970. року у Новим Садзе. То награда републичного значеня а додзелює ю Дружтво за старанє о дзецох Социялистичней Республики Сербиї за найлепши оствареня 3 литератури за дзеци на териториі Социялистичней Републики Сербиї у цеку єдного року.

Щиро Вас поздравям.

Мирон Будински

Нови Сад, Олге Петров 22

Нови Сад,

10. октобра 1970.

Підкреслімо найцікавіший елемент цього листа - ствердження Будинського про “огранїченосц язика” русинів Бачки і Срема. Факт цілком очевидний, але автор стверджує, що представники громади гостро відчувають на собі обмеженість мовної аудиторії. Задля певної компенсації такого стану речей русини вживають заходів: наприклад, вибір казки як форми самовираження був особистою стратегією письменника - подолати кордони за допомогою універсальної мови цього жанру. Тенденція шукати “людзох у далєким швеце” - це ще один спосіб пошуку читацької аудиторії. Цей спосіб сам Будинський вважає 
наївним, але книжку до українського науковця все ж надсилає. Безсумнівно, Мишанич був у очах Будинського представником не стільки України, скільки СРСР (“отечество таке вельке”). Утім той факт, що український науковець цілком відверто інтерпретував громаду русинів як частину українського світу, знов таки, не зупинив Будинського. Мишанич був науковцем, а не політиком, i цілком об'єктивно сприймав самобутність мови і культури русинів як факт, що не суперечить належності русинів до спільного з українцями коріння. Так само як М.Ковач, який присвятив ціле життя літературному вдосконаленню своєї рідної мови, не мусив задля цього відмовлятися від “українізму”, проти якого так гаряче висловлювався Будинський у наведених вище матеріалах.

Твори Будинського перекладено македонською, румунською, сербською, словацькою, угорською та українською мовами. Перші п'ять $\epsilon$ офіційними мовами Югославії та, зокрема, Воєводини, отже $\epsilon$ природнім, що твори цього югославського письменника були опубліковані цими мовами. Українська мова сягає за межі держави і в Югославії не мала жодного статусу. У цих умовах, можливість численних русинів-письменників “отвориц облак до швета” залежала, між іншим, від того факту, що увагу українського вченого Мишанича привернула їхня громада 3 українським (чи то руським), хоча й віддаленим корінням. Ми не можемо знати, чи відбився цей важливий факт у свідомості Мирона Будинського, але його лист можна інтерпретувати як бажання отримати той самий 'привілей', якого він колись так хотів позбавити М.Ковача - можливість розширити свої творчі краєвиди через використання творчого зв'язку 3 тим середовищем, що вважало його ближчим і важливішим за будь-яку іншу творчу одиницю. І це завдяки завдяки усвідомленню спільного коріння, та незважаючи на відстань у часі і просторі.

Невідомо, чи отримав М.Будинський відповідь від українського науковця. Відомо, що Енциклопедія Сучасної України, що їі засновано 2001 р., містить статтю академіка О.В.Мишанича про Мирона Будинського, де він значиться як “український письменник і педагог у Сербії і Чорногоріі” (Мишанич, без дати). 
Відділ рукописних фондів і текстології Інституту літератури ім. Т.Г. Шевченка НАН України - Фонд № 232.

\section{ЛІТЕРАТУРА}

Будински, М. (1955). Думки з нагоди Дзешещрочнйщи снованя нашей гимназиї (Здогадованя). Руске слово", 14/01/1955.

Будински, М. (1970). Здогаднїме ше. В: Народни календар 1970, 45-51. Конєи школского року нашей гимназиї. "Руске слово", 27/VII.45, 2.

Мишанич, О.В. (2020). Будинський Мирон. [інтернет-видання] Енциклопедія сучасної України, http://esu.com.ua/search_ articles.php?id=36511 (дата останнього перегляду: ( 26/09/2020)

Планчак, Е. (1945). Виривка 3 дискусиї $з$ нагоди основаня «Рускей Матки». Становиско Йовгена Планчака, шк. инструктора. Руске слово, 2/11/1945, 4.

Рамач, Я. (2019). Співпраця Олекси Горбача з русинами Югославії у 5060-х роках ХХ ст. Проблеми слов'янознавства 68/2019, 126-136.

Румянцев, О. (2015). «Боротьба за правопис» серед бачванськосремських русинів. у: Slavic Alphabets in Contact, Vittorio Springfield Tomelleri, Sebastian Kempgen (eds.), University of Bamberg Press Bamberg, 2015, 189-207.

Румянцев, О. (2010). Питання національної ідентичності русинів $i$ украӥнців Югославї (1918-1991), München-Berlin, Verlag Otto Sagner, 2010.

Софронів-Левицький, В. (1970). Кланялися вам три Украӥни. Репортаж про туристичний маратон по украӥнських поселеннях $у$ Ютославії, Чехословаччині і Польщі. Торонто: Новий шлях, 1970.

Тамаш, Ю. (1997). История рускей литератури. Београд: Завод за уџбенике и наставна средства, 1997, 202-203.

Умар Мирон Будински (1931-2018). Руске слово 4/06/2018, http://www.ruskeslovo.com/Умар-Мирон-Будински-1931-2018/ (дата останнього перегляду: 26/09/2020).

Х.X. (1955). Мушиме трезбейше патриц на Українизам. Руске слово, 28/01/1955, 3 .

Чурчич М. Библиография Руснацох у Югославиї 1918-1980. Нови Сад: Библиотека Матице српске, 2006. 
Budinski, M. (1970). Dumki z nagodi Dzešecročn'ci snovanâ našej g̀imnaziï (Zdogadovanâ). "Ruske slovo", 14/01/55.

Budinski, M. (1970). Zdogadnïme še. V: Narodni kalendar 1970, 45-51.

Calvi, L. (1999). Minoranza grazie alle maggioranze: i rusyny-rusnaci dell'ex-Jugoslavia. Letterature di Frontiera. 2/IX, 1999, 139-151.

Konêc školskogo roku našej gimnaziï. Ruske slovo, 27/VII.45, 2.

Mišanič, O.V. (2020). Budinskij Miron. [internet-vidannâ] Enciklopedîâ sučasnoï Ukraïni， http://esu.com.ua/search_articles.php?id=36511 (data ostann'ogo pereglâdu: 26/09/2020)

Plančak, E. Virivka $\mathrm{z}$ diskusiï $\mathrm{z}$ nagodi osnovanâ «Ruskej Matki». Stanovisko Jovg̀ena Plančaka, Šk.instruktora, Ruske slovo, 2/11/1945, 4.

Ramač, Â. (2029). Spìvpracâ Oleksi Gorbača z rusinami Ûgoslaviï u 50-60-h rokah XX st. Problemi slov'ânoznavstva, 68/2019, 126-136.

Rumâncev, O. (2015). «Borot'ba za pravopis» sered bačvans'ko-srems'kih rusinìv. u: Slavic Alphabets in Contact, Vittorio Springfield Tomelleri, Sebastian Kempgen (eds.), University of Bamberg Press Bamberg, 2015, 189-207.

Rumâncev, O. (2010). Pitannâ nacional noï identičnostì rusinìv ì ukraïncìv Ûgoslaviï (1918-1991), München-Berlin, Verlag Otto Sagner, 2010.

Sofronìv-Levic'kij, V. (1970). Klanâlisâ vam tri Ukraïni. Reportaž pro turističnij maraton po ukraïns'kih poselennâh u Ûgoslaviï, Čehoslovaččinì ì Pol'ŝì. Toronto: Novij šlâh, 1970.

Tamaš, Û. (1997). Istoriâ ruskej literaturi. Beograd: Zavod za uџbenike i nastavna sredstva, 1997, 202- 203.

Umar Miron Budinski (1931-2018). Ruske slovo 4/06/2018, http://www.ruskeslovo.com/Umar-Miron-Budinski-1931-2018/ (data ostann'ogo pereglâdu: 26/09/2020).

Čurčič M. (2006). Bibliog̀rafiâ Rusnacoh u Ûgoslaviï 1918-1980. Novi Sad: Biblioteka Matice srpske, 2006.

Umar Miron Budinski (1931-2018). Ruske slovo, 4/06/2018, H.H. Mušime trezbejše patric na Ukraïnizam. Ruske slovo, 28/01/1955, 3. 
Oleg Rumyantsev

M. BUDYNSKY'S LETTER TO O. MYSHANYCH (1970)

IN THE CONTEXT OF THE QUESTION OF THE IDENTITY OF THE RUTHENIANS BACHKA AND SREM

\section{Summary}

The article analyze the attitude of writer Miron Budinsky to the question of the identity of the Ruthenians oa Bačka and Syrmia. The article contains an unpublished letter from M.Budinsky to the Ukrainian scholar O.Myshanych.

Keywords: Miron Budinsky, Oleksa Myshanych, Mihajlo Kovach, Yugoslavia, Ruthenians, Ukrainians, identity. 